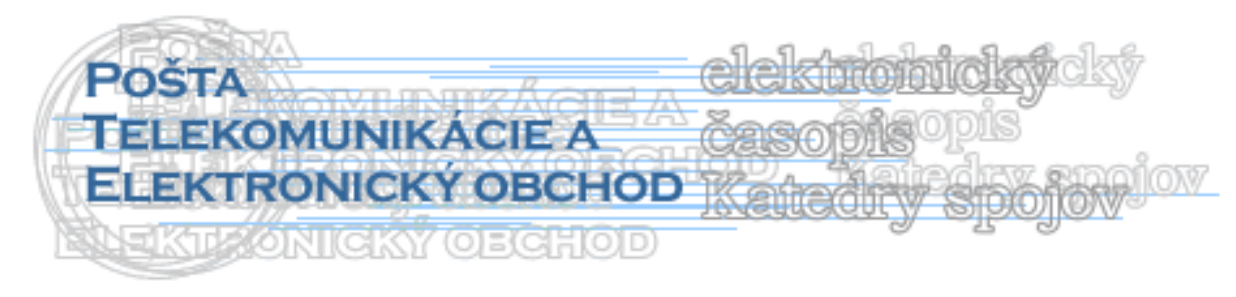

\title{
POZÍCIA HODNOTENIA PRACOVNÍKOV PRI RIADENÍ PRACOVNÉHO VÝKONU V SPOJOVÝCH PODNIKOCH
}

\author{
Kvetoslava Mišiaková*, Soňa Stránska**
}

\section{Úvod}

Riadenie pracovného výkonu predstavuje nový strategicky orientovaný proces, ktorý umožňuje zamestnancom pochopit', na čo sa majú vo svojej práci orientovat' a čo majú dosiahnut'. Ide o taký prístup $\mathrm{k}$ riadeniu, $\mathrm{v}$ ktorom sa predpokladá neustála komunikácia medzi zamestnancom a jeho nadriadeným o práci, ktorá sa má urobit'.

Ciel'om tohto integrovaného procesu je dosahovanie neustáleho zdokonal'ovania pracovného výkonu jednotlivca a tým aj zvyšovanie výkonnosti celej firmy.

Súčast’ou tohto procesu je plánovanie pracovného výkonu a jeho monitorovanie $\mathrm{v}$ priebehu roka, celkové hodnotenie pracovného výkonu, vzdelávanie a rozvoj zamestnancov a ich odmeňovanie. Tento prístup $\mathrm{k}$ riadeniu pracovného výkonu smeruje $\mathrm{k}$ zvyšovaniu výkonu zamestnancov poskytnutím informácií o ciel'och, ktoré je treba dosiahnut'. Následne na to sa poskytujú informácie o potrebnom rozvoji.

\section{Hodnotenie pracovného výkonu}

Pri posudzovaní výkonu zamestnanca, prípadne skupiny, je potrebné určit' kritériá výkonu, ktoré musia byt' primerané hodnotenej práci a mat' dostatočnú vypovedaciu schopnost'. Základnými a do určitej miery univerzálnymi kritériami sú:

- kvantita vykonanej práce za určitý časový úsek,

- kvalita práce za určitý časový úsek,

- včasnost' plnenia pracovných úloh,

- stabilita výkonu v čase,

- výskyt a frekvencia chybného jednania.

Tieto kritériá však zvyčajne nepostačujú na hodnotenie pracovného výkonu a je potrebné ich doplnit' o d'alšie a detailnejšie. Použité kritériá sú do značnej miery

\footnotetext{
*Ing. Kvetoslava Mišiaková, Žilinská univerzita v Žiline, Fakulta prevádzky a ekonomiky dopravy a spojov, Katedra Spojov, Univerzitná 1, 01026 Žilina, Slovenská republika, tel.: +421 911286898, E-mail: Kvetoslava.Misiakova@fpedas.uniza.sk

*Ing. Soňa Stránska, Žilinská univerzita v Žiline, Fakulta prevádzky a ekonomiky dopravy a spojov, Katedra Spojov, Univerzitná 1, 01026 Žilina, Slovenská republika, tel.: +421 903 121317, E-mail:

Sona.Stranska@fpedas.uniza.sk
} 
determinované použitými metódami hodnotenia, ktorých je pomerne vel'a a majú niekol'ko d'alších variant. Ovel'a zložitejšie je hodnotenie pracovného výkonu pri odborných pracovníkoch, prípadne manažéroch. Do úvahy je potrebné zobrat' taktiež faktor času. Pracovné výstupy za hodnotené obdobie, totiž s daným obdobím časovo vôbec nemusia súvisiet'. Preto je potrebné prihliadat' pri hodnotení na možný časový posun medzi činnost’ou pracovníka a výsledným výstupom tejto činnosti. Taktiež pri hodnotení manažéra je potrebné hodnotit' jeho osobnú výkonnost', ako aj výkonnost' skupiny, ktorú vedie. To čo pri jeho hodnotení sledujeme je totiž výkon celej skupiny, ale manažér k nemu musí tiež pridávat' hodnotu. Úlohou hodnotenia je zistit' „výšku“ tohto vkladu.[1]

\section{Hodnotenie zamestnancov}

Hodnotenie zamestnancov tvorí súčast' personálnej práce organizácie. Poslaním hodnotenia je spoznat' a racionálne využit' profesijnú kvalifikáciu zamestnancov, vhodne rozvíjat' ich pracovnú kariéru, motivovat' ich a prispiet' $\mathrm{k}$ spravodlivému odmeňovaniu. Hodnotenie je dôležité i pre kvalifikované posúdenie reálnosti zvládnutia niektorých úloh uvažovanými l'ud'mi, menovaním do vyšších funkcií, zmenu pracovného zaradenia, preradenie na iné pracovisko, zvyšovaním kvalifikácie, rekvalifikácie, ukončenie pracovného pomeru.

Hodnotenie zamestnancov sa využíva pri personálnej práci s každým zamestnancom. Má však i širšie poslanie ako súčast' komplexnej riadiacej práce manažérov firmy k identifikácii rezerv l’udských zdrojov, k objektivizácii potreby zmien kvalifikácie a rekvalifikácie, $\mathrm{k}$ hodnoteniu a zmenám odmeňovania, stimulácie a motivácie.

Hodnotenie zamestnancov je záverečný krok procesu riadenia pracovného výkonu. Zaoberá sa zist'ovaním, ako pracovník vykonáva svoju prácu, aké je jeho pracovné správanie, aké sú vzt’ahy $\mathrm{k}$ spolupracovníkom, zákazníkom a iným osobám, s ktorými v súvislosti s výkonom práce prichádza do styku. Zistené výsledky sú prerokovávané so zamestnancami a hl'adá sa cesta $\mathrm{k}$ zlepšeniu pracovného výkonu .

Je možné povedat', že hodnotenie pracovníkov predstavuje jednotu zist'ovania, posudzovania, úsilia o nápravu a stanovenie ciel'ov týkajúcich sa pracovného výkonu a je považované za účinný nástroj kontroly, usmerňovania a motivovania pracovníkov.[2]

Medzi hlavné možnosti využitia hodnotenia zamestnancov patria:

- Zistenie momentálnej úrovne pracovného výkonu pracovníka.

- Rozpoznanie silné a slabé stránky pracovníka a následné zlepšenie jeho výkonu.

- Rozpoznanie rezervy pracovného výkonu zamestnanca.

- Odmeňovanie podl'a zásluh.

- Motivovanie pracovníkov.

- Rozhodovanie o povýšení pracovníkov, vytvorenie podkladov pre plánovanie kariéry.

- Rozpoznanie potreby vzdelávania a rozvoja pracovníkov.

- Zlepšovanie vzt’ahov medzi pracovníkmi a ich nadriadenými.

- Vyhodnocovanie efektívnosti výberu a prijímania pracovníkov.

\subsection{Kto hodnotí zamestnancov}

Zamestnancov hodnotí [2]:

- Bezprostredný nadriadený

- Nadriadený bezprostredného nadriadeného

- Zamestnanec personálneho útvaru

- Nezávislý externý hodnotitel' 
- Sám zamestnanec-Sebahodnotenie

- Podriadený

- Spolupracovník, alebo skupina spolupracovníkov

- Tím

- Assessment centre

\subsection{Proces hodnotenia zamestnancov}

Proces hodnotenia zamestnancov sa rozdel'uje do troch fáz a to sú [2] :

- Prípravné obdobie

- Obdobie získavania informácií

- Obdobie vyhodnocovania informácií

\section{Prípravné obdobie}

V tomto období sa stanovujú zásady, pravidlá a postupy hodnotenia a vytvárajú sa formuláre, ktoré sú používané $\mathrm{k}$ hodnoteniu pracovného výkonu zamestnanca.

Ďalej sa analyzujú pracovné miesta, formulujú sa kritéria výkonu a jeho hodnotenia, vyberajú sa metódy hodnotenia. V závere prípravného obdobia sa informujú pracovníci o pripravovanom hodnotení a jeho účele, o kritériách a normách pracovného výkonu a aký výkon sa od nich vlastne očakáva.

Obdobie získavania informácií.

Náplňou je zaobstarat' si dokumentáciu o pracovnom výkone. Písomný záznam je vel'mi dôležitý, pretože k záznamom je možné kedykol'vek sa vrátit' a získat' tak retrospektívnu informáciu .

Obdobie vyhodnocovania informácii

Do tohto obdobia patrí vyhodnocovanie pracovných výsledkov a pracovného správania. Zvyčajne sa porovnávajú skutočné výsledky práce s normami výkonu alebo očakávanými výsledkami práce. Existuje pritom riziko subjektívneho prístupu. pretože aj objektívne ukazovatele výkonu je treba interpretovat'. Dalej tu zarad'ujeme rozhovor s hodnotením pracovníkom o výsledkoch hodnotenia a o možných cestách riešenia problémov, ktoré súvisia s pracovným výkonom. Práve táto fáza je rozhodujúca pre zlepšovanie pracovného výkonu pracovníka.

\subsection{Ciele hodnotenia zamestnancov}

Hlavné ciele, ktoré chce organizácia v oblasti hodnotenia dosiahnut' :

- hodnotenie, ktoré umožňuje organizácii spravodlivo rozdel'ovat' peniaze, vecné odmeny a funkčný postup zamestnancov,

- revízia, ktorá odhal'uje súčasný aj budúci pracovný potenciál jednotlivcov aj útvarov,

- vytváranie plánov funkčného postupu pre l’udské zdroje a pre plánovanie na úrovni jednotlivých útvarov ako aj celej organizácie,

- identifikovanie potrieb odbornej prípravy zamestnancov pomocou odhal'ovania chýb a nedostatkov, ktoré by sa mohli po vhodnej odbornej príprave odstránit',

- motivovanie pracovného kolektívu, ktoré zaručuje plnenie noriem a ciel'ov organizácie,

- rozvíjanie zamestnancov poskytovaním rád alebo využívaním pochvál a trestov ako prostriedok na formovanie ich správania, 
- kontrolovanie efektívnosti používaných postupov a praktík personálneho oddelenia.

\subsection{Formy hodnotenia zamestnancov}

Rozoznávame dve podoby hodnotenia zamestnancov :

- neformálne hodnotenie, tzv. priebežné hodnotenie zamestnancov jeho nadriadeným počas vykonávania práce. Ide v podstate o súčast' každodenného vzt'ahu medzi nadriadeným a podriadeným, súčast' priebežnej kontroly plnenia pracovných úloh a pracovného správania. Neformálne hodnotenie sa však nezaznamenáva a len výnimočne býva príčinou personálneho rozhodnutia.

- formálne hodnotenie je väčšinou racionálnejšie a štandardizované, má pravidelný interval a jeho charakteristickými rysmi sú plánovitost' a systematickost'. Vedú sa o ňom záznamy v podobe dokumentov, ktoré slúžia ako podklady pre d’alšie personálne činnosti týkajúce sa jednotlivca i skupín zamestnancov.

Formálne i neformálne hodnotenie sa môže uskutočňovat' každodenne alebo priebežne, príležitostne alebo systematicky.

\subsection{Kritéria hodnotenia zamestnancov}

Kritéria hodnotenia zamestnancov sú stanovené na základe charakteristík pracovných miest - popisov a špecifikácií práce. Pre hodnotenie zamestnancov musia byt' definované konkrétne kritériá. V teórii aj v praxi sa stretávame s rôznymi prístupmi pri ich vymedzovaní a vyjadrovaní určitými ukazovatel'mi, čo súvisí najmä so snahou eliminovat' subjektívnost' pri hodnotení zamestnancov. Napriek tomu existujú určité typické kritériá, ktoré sa pri hodnotení používajú :

- hodnotenie pracovnej role (napr. kvalita a kvantita plnenia zadaných i d'alších úloh, umenie viest' spolupracovníkov)

- správanie v priebehu pracovného procesu, prípadne $i$ mimo neho (napr. obetavost', iniciatíva, inovačná aktivita, disciplína, úroveň absencie, vzt’ah ku kolektívu, pôsobenie na spolupracovníkov)

- osobné a charakterové črty (napr. čestnost', svedomitost', poctivost', spôsob vystupovania, lojalita voči firme)

- perspektívnost' pre firmu (napr. hl'adisko veku, nahraditel'nosti, záujem spojit' pracovnú kariéru s firmou, vymedzenie oblasti uplatnenia a jej doba)

Podl'a rozdielneho poslania sa hodnotenie $\mathrm{v}$ organizáciách niekedy klasifikuje do špecifických skupín, a to podla účelu, spôsobu a podrobnosti realizácie hodnotenia a pod. Môže íst' napr. o hodnotenie doterajšej pracovnej činnosti (úspechu, chýb, správania, lojality voči firmy a pod.), hodnotenie predpokladov pre zmenu pracovného zaradenia, hodnotenie za účelom spravodlivého odmeňovania (porovnanie so spolupracovníkmi, dôvody pre zmenu a pod.). [26]

Hodnota kritérií sa môže vyjadrit' číselne (bodovacia stupnica) alebo slovne. Za vhodnejšie sa považuje číselné vyjadrovanie kritérií s následným zostavením poradia hodnotených. Konkrétne systémy hodnotenia sa rozpracovávajú podl'a hodnotenia podmienok jednotlivých podnikov.

Hodnotenie podl'a rôznych kritérií sa niekedy môže doplňovat' i čiastočne prekrývat'. Podstatný je výber kritérií a snaha využívat' ich v rozumnej miere a u skupiny l’udí, kde to má opodstatnenie. 


\subsection{Metódy hodnotenia zamestnancov}

V okamihu, ked' si organizácia zvolí jednotlivé kritériá musí určit' spôsob akým budú sledované a zaznamenávané. Pri vel'kom množstve kritérií, ktoré možno sledovat' existuje i celá rada metód, ktoré je možné k tomu použit'. Podobne ako hodnotiace kritériá, tak i použité metódy hodnotenia sa líšia v závislosti na type organizácie, charaktere pracovnej činnosti a zainteresovanosti zamestnanca. Ked’že hodnotenie má byt'individuálny proces, metód hodnotenia je nespočetné množstvo a majú vel’a variant.

V odbornej literatúre [2, 3 ] sa uvádza celý rad rôznych metód hodnotenia.

Najčastejšie sa hodnotenie vykonáva týmito metódami :

- Verbálna metóda (popisná) : je neformálna, bez použitia formulárov. Hodnotitel' posudzuje zamestnanca verbálne, obvykle písomnou formou. Úlohou hodnotitela je podat' výstižný a úplný hodnotiaci popis zamestnanca. Je spojená s rizikom subjektivity, a preto je doplňovaná inými metódami.

- Porovnanie so stanovenými ciel'mi : pri tejto metóde zamestnanec spolupracuje so svojím nadriadeným na predbežnom určení ciel'a, použitie tejto techniky vyžaduje, aby zamestnanec formuloval tieto ciele vo forme meratel'ných a sledovatel'ných výstupov a výsledkov. Hodnotenie potom spočíva v spoločnom posúdení miery, v akej bol ciel' dosiahnutý.

- Metóda posudzovacích stupníc : toto hodnotenie je založené na presnom definovaní štandardného kritéria a jednotnej posudzovacej škály.

\section{Typy posudzovacích skupín :}

- numerická bodovacia stupnica, kedy je každé kritérium odstupňované pomocou čísel alebo bodov. Hodnotenie potom môže byt' vyjadrené súhrne počtom dosiahnutých bodov pri všetkých posudzovacích kritériách, pričom význam kritérií môže byt' vyjadrený odlišným bodovým rozpätím.

- grafická stupnica, kedy je hodnotenie u každého kritéria vyznačené na priamke. Súhrnné hodnotenie všetkých posudzovaných znakov sa vyjadruje krivkou, ktorá vznikne spojením dosiahnutých výsledkov. Táto krivka jasne dokumentuje prednosti a nedostatky posudzovaného zamestnanca.

- verbálna (slovná) stupnica, kedy sú stupne hodnotenia vyjadrené prídavným menom (napr. výborný, vel'mi dobrý, dobrý, vyhovujúci a nevyhovujúci) alebo stručnou situačnou charakteristikou hodnoteného zamestnanca.

- kombinácia vyššie uvedených typov, kedy je obyčajne pre každý stupeň vyjadrený slovne alebo situačnou charakteristikou stanovený určitý počet bodov.

- Porovnanie s pracovnými normami : porovnajú sa objektívne štandardy pracovného výkonu s správania zamestnancov, ich vlastnost’ami a d’alšími charakteristikami. Pozorovanie správania zamestnancov sa môže uskutočňovat', napr. fyzickým sledovaním výkonu, správania, telesnej kondície a návykov zamestnancov.

- Dotazník : pri tejto metóde označuje hodnotitel' pri presne formulovaných hodnotiacich otázkach správne odpovede, vyplnený dotazník sa analyzuje a slúži ako podklad pre spracovanie hodnotenia.

- Metóda kritických prípadov : pri tejto metóde ide o charakteristiku hraničných situácií, tzv. vysoko produktívneho a vysoko neproduktívneho správania zamestnanca za určité sledované obdobie pri vybraných pracovných úlohách. Metóda vyžaduje, aby 
hodnotitel' viedol písomné záznamy o prípadoch, ktoré sa stali pri vykonaní práce určitého zamestnanca.

- Zaradenie pracovníkov podl'a výkonov : zoradením od najvýkonnejšieho po najmenej výkonného je jednoduché, rýchle, l'ahko zrozumitel'né a lacné.

- Hodnotiaca správa : v takejto správe hodnotitel' popisuje silné a slabé stránky správania zamestnanca za určité časové obdobie. Správy môžu byt' zostavené na základe denníkov, ktoré hodnotitel' po určitú dobu vedie, a v ktorých sleduje hraničné situácie.

\subsection{Chyby pri hodnotení zamestnancov}

Závažné omyly v hodnotení zamestnancov môžu znížit' hodnotu sledovaného výkonu a môžu mat' nepriaznivý vplyv na rozhodovanie v personálnej oblasti. Chyby pri hodnotení, s ktorými sa najčastejšie stretávame sú [2] :

- Haló efekt : znamená tendenciu hodnotit' na základe celkového dojmu a zakrývat' tak rozdiely medzi jednotlivými kritériami. To môže viest' k výbornému hodnoteniu pracovného výkonu len preto, že sledovaný pracovník je príjemný spoločník.

- Zhovievavost'/prísnost' : zhovievavost' je tendencia posudzovat' celú skupinu zamestnancov viac menej kladne, prísnost' je tendencia opačná.

- Snaha spriemerňovat' : zamestnanci sú väčšinou hodnotení ako priemerní.

- Efekt nedávnosti : pri využívaní subjektívneho charakteru hodnotenia dochádza k silnému ovplyvňovaniu nedávnymi činmi zamestnanca.

- Zaujatost' vyplývajúca z rozdielnosti kultúr : každá hodnotiaca osoba má o l’udskom správaní určité predstavy, založené na kultúrnom prostredí, z ktorého vyšla. Ak majú l'udia hodnotit' zamestnanca, ktorí pochádza z iného kultúrneho prostredia, budú aplikovat' svoje predstavy založené na inom rebríčku hodnôt.

- Osobné predsudky : neznášanlivost' hodnotitel'a ku skupine alebo triede l'udí môže tiež skresl'ovat' hodnotenie, ktoré títo l'udia dostávajú.

Úspešný systém hodnotenia pracovného výkonu vyžaduje viac než len použitie vhodnej metódy. K základným dvom problémom, s ktorými sa pri realizácii procesu hodnotenia stretávame je, aby hodnotitel' pochopil podstatu hodnotenia, a aby hodnotenie bolo dôsledné. Niektoré personálne oddelenia vydávajú smernice s popisom príslušných procesov, ktoré obsahujú informácie o uskutočnení hodnotenia, o kritériách hodnotenia, organizujú školenia s ciel'om odbornej prípravy hodnotitel'ov. Po ukončení odbornej prípravy hodnotitel'ov môže začat' samotný proces hodnotenia.

O výsledkoch hodnotenia sú zamestnanci informovaní prostredníctvom hodnotiacich pohovorov. Ciel'om takéhoto pohovoru je zdôraznit' priaznivé aspekty pracovného výkonu zamestnanca.

Takýto pozitívny prístup umožní i samotnému hodnotiacemu zamestnancovi rozšírit' si vlastnú predstavu o kladných i záporných prvkoch práce, pretože nemá pocit, že je hodnotený len negatívne. Ak sa hovorí o negatívnych javoch, je potrebné sa zamerat' na prácu ako takú, nie na osobnost' zamestnanca. Je potrebné uviest' konkrétne príklady zamestnancových nedostatkov, aby vedel, čo má vo svojej práci zlepšit'. [4]

Hodnotiaci pohovor by mal byt' ukončený rozborom činností, ktoré by mali napomôct' zlepšit' slabé stránky pracovného výkonu zamestnanca. V tejto záverečnej časti hodnotiaceho pohovoru by mal hodnotitel' navrhnút' svoju pomoc pri prekonávaní nedostatkov zamestnanca. 
Hlavnou požiadavkou pre súčasnú etapu je, aby sa hodnotiace pohovory v praxi uskutočňovali, aby sa nadriadený stretol s podriadeným a prediskutovali spolu problémy a otázky, ktoré obidvoch zaujímajú. [5]

Nový prístup $\mathrm{k}$ hodnoteniu presúva hlavný dôraz z určenia pracovného potenciálu na komunikáciu. Hlavným ciel’om je zdokonal'ovat' komunikáciu a pracovné vzt'ahy medzi nadriadenými a ich podriadenými, čím sa sleduje dosiahnutie vyššieho pracovného výkonu. Namiesto nepríjemného dialógu hovoríme o hodnotnom dialógu, ktorý vedie k zlepšeniu vertikálnej komunikácie a informovanosti v podniku a ku zvýšeniu motivácie hodnoteného zamestnanca.

\section{Záver}

Hodnotit' správanie je dôležité, pretože odráža spôsob, akým zamestnanec dosahuje výsledky, ako jednotlivci komunikujú, podporujú tím a učia iných. Stretávame sa s príkladmi, ked' zamestnanec dosahuje výborné výsledky, ale je t’ažké s ním spolupracovat'. Toto jeho správanie môže odrádzat' od výkonu jeho ostatných kolegov. Na druhej strane, zamestnanec môže byt' extrémne nápomocný iným kolegom, ale nikdy nedosiahne patričný výsledok. Pri hodnotení správania definuje firma a manažér svoje očakávania od svojho podriadeného na základe firemných hodnôt $\mathrm{v}$ prípade zamestnanca alebo manažérskych kompetencií v prípade manažéra.

V hodnotiacom procese je dôležitá vol'ba hodnotiacich metód, ktorých majú podniky k dispozícii širokú škálu. Najčastejšie sa však používajú dve základné metódy. Vyplnenie hodnotiaceho dotazníka, na ktorý by mal bezprostredne nadviazat' hodnotiaci pohovor.

Realita však ukazuje, že časový rozdiel medzi vyplnením hodnotiaceho dotazníka, ktorý má byt' okrem iných dokumentov podkladom pre hodnotiaci pohovor a uskutočnením hodnotiaceho pohovoru, je zväčša vel'mi dlhý. Hodnotitelia nemajú väčšinou na vyplňovanie hodnotiaceho dotazníka v práci dostatok času. To isté platí aj pre hodnotiace pohovory. Hodnotitel' nemá čas na samotnú prípravu ako aj na jeho realizáciu. Celý proces hodnotenia tým pádom prebieha len akoby „, pro forma“. Hodnotitelia vychádzajú z nariadenia, že “je stanovené, že máme hodnotit', tak musíme vykázat', že sme hodnotili, nie je podstatné ako"a výsledok hodnotenia v tomto smere stráca svoje opodstatnenie.

Myslíme si, že existuje spôsob, ako vyriešit' tento problém. V prvom rade je potrebné zmenit' celkový postoj zamestnancov, je nutné zmenit' spôsob ich myslenia a ich prístup $\mathrm{k}$ práci a $\mathrm{k}$ podniku. Ide o proces komplikovaný a časovo náročný.

Hodnotitel' môže zvýšit' precíznost' prevedenia hodnotenia tím, že spoločnost' umožní hodnotitel'ovi širšie uplatnenie metód a dá mu priestor k väčšej kreativite v tomto procese.

Vo fáze realizácie hodnotiaceho systému vznikajú problémy súvisiace nie len so samotným procesom hodnotenia, ktoré sme už uviedli, ale aj problémy samotných zamestnancov, s ktorými sa stretávajú pri snahe o jeho zrealizovanie. Tieto problémy sa týkajú hlavne spôsobov riešenia konfliktných situácií, akým spôsobom eliminovat' svoj sklon $\mathrm{k}$ priemernosti, $\mathrm{k}$ miernosti alebo naopak $\mathrm{k}$ prílišnej prísnosti $\mathrm{k}$ hodnotenému, spôsobov ako sa vyvarovat' pri hodnotení od prihliadania na príbuzenské a priatel'ské vzt'ahy.

K problematickým otázkam hodnotitel'a patrí najmä neschopnost' prezentovat' výsledky hodnotenia, či vhodne podat' kritiku respektíve pochvalu priamo zamestnancovi. Zo strany hodnoteného sa najčastejšie objavuje problém akým spôsobom prijat' hodnotenie a ako sa vyrovnat's výsledkom hodnotenia.

Najzávažnejším a podstatným nedostatkom je, že i ked' proces hodnotenia je už dávno zavedený v podniku, jeho pracovníci stále úplne nechápu jeho podstatu a význam. 
So záverečnou fázou hodnotenia súvisí jeho význam, ktorý pripisujú spoločnosti najmä dvom oblastiam. Jedná sa $\mathrm{v}$ prvom rade o odmeňovanie a taktiež oblast' neustáleho zlepšovania pracovného výkonu zamestnanca, ale pritom sa zabúda na vel'mi dôležité oblasti a to zlepšenie vzájomnej komunikácie v rámci spoločnosti a d'alšie vzdelávanie zamestnancov.

Ako každá činnost' i hodnotenie si vyžaduje, aby sa ho človek naučil a osvojil. Vo vel'kých podnikoch musia byt' nástroje štandardizované, pretože ich používa viac l'udí a každý má subjektívne vnímanie.

Význam hodnotenia pracovného výkonu pracovníkov spočíva v tom, že organizácia získava presnejšie informácie o svojich zamestnancoch, čo jej umožňuje lepšie plánovat' ich mobilitu, správne využívat' ich pracovný a tvorivý potenciál a na základe toho optimalizovat' personálnu štruktúru.

Pre pracovníka je hodnotenie pracovného výkonu dokladom, že firma prejavuje záujem o jeho prácu, že vie rozlíšit' kvalitnú a nekvalitnú prácu, vyzdvihnút' úspešných a napomenút' neúspešných zamestnancov.

Myslíme, že k zdokonaleniu prevedenia tohto systému, je potrebné zmenit' jednu podstatnú skutočnost'. Je nevyhnutné neustále pracovat' na formovaní prístupu jednotlivých zúčastnených subjektov, od vedenia podniku cez personálne oddelenie až po rádového zamestnanca, k otázkam riadenia l’udských zdrojov.

V prvom rade je potrebné venovat' vel'kú pozornost' celkovému postoju zamestnancov, ich spôsobu myslenia a prístupu k práci a podniku a ich motivácii. Ide o proces komplikovaný a časovo náročný. Prostriedky na zvýšenie iniciatívy a dôslednosti realizácie hodnotenia, sú v kompetencii personálnych oddelení a vedenia podnikov. Ich úlohou je poukázat' na konkrétne dôsledky hodnotenia v prospech svojich zamestnancov. Máme na mysli dôsledky v oblasti možnosti d’alšieho vzdelávania, kariérneho postupu či odmeňovania.

\section{Literatúra}

[1] BÁBELOVÁ, Z.: Vplyv výkonnosti zamestnancov na výkonnost’ podniku. [online]. [Citované 2007-12-20]. Dostupné na: http://www.fce.vutbr.cz/veda/dk2004texty/pdf/05_Ekonomika\%20a\%20rizeni\%20stav ebnictvi/5_02_Ekonomika\%20stavebniho\%20podniku/Babelova_Zdenka.pdf

[2] KOUBEK, J. Rízení lidských zdrojů. Základy moderní personalistiky. Management Press, Praha, 2001. ISBN 80-7261-033-3.

[3] ARMSTRONG, M.: Ř́zení lidských zdrojů. Grada Publishing, Praha, 2002. ISBN 80247-0469-2.

[4] WERTHER, W.B. - DAVIS, K. : Lidský faktor a personální manažment, Victoria Publishing, Praha, 1992. ISBN 80-85605-04-X.

[5] BOROVEC, J. : Hodnocení zamestnanců v ABB ČR. In: Moderní řizení. Praha, Economia, 1996, č. 10, str.59. 